\title{
BIRTH AND MORTALITY OF MANED WOLVES Chrysocyon brachyurus (ILLIGER, 1811) IN CAPTIVITY
}

\author{
MAIA, O. B. ${ }^{1}$ and GOUVEIA, A. M. G. ${ }^{2}$ \\ ${ }^{1}$ Consultor do Plano de Manejo do Lobo-guará \\ ${ }^{2}$ Escola de Veterinária da Universidade Federal de Minas Gerais \\ Correspondence to: Otávio Borges Maia, Laboratório de Virologia Animal, Departamento de Medicina Veterinária \\ Preventiva, C.P. 567, CEP 30123-970, Belo Horizonte, \\ Minas Gerais, Brazil, e-mail: otazoo@bol.com.br \\ Received January 25, 2000 - Accepted July 17, 2000 - Distributed February 28, 2002
}

(With 5 figures)

\begin{abstract}
The aims of this study were to verify the distribution of births of captive maned wolves Chrysocyon brachyurus and the causes of their deaths during the period from 1980 to 1998, based on the registry of births and deaths in the International Studbook for Maned Wolves. To determine birth distribution and average litter size, 361 parturitions were analyzed for the 1989-98 period. To analyze causes of mortality, the animals were divided into four groups: 1. pups born in captivity that died prior to one year of age; 2 . animals born in captivity that died at more than one year of age; 3 . animals captured in the wild that died at any age; and 4. all animals that died during the 1980-98 period. In group 1, the main causes of mortality were parental incompetence (67\%), infectious diseases, $(9 \%)$ and digestive system disorders $(5 \%)$. The average mortality rate for pups was $56 \%$. Parental incompetence was responsible for $95 \%$ of pup deaths during the first week of life. In group 2 , the main causes were euthanasia (18\%) and disorders of the genitourinary (10\%) and digestive systems (8\%). Euthanasia was implemented due to senility, congenital disorders, degenerative diseases, and trauma. In group 3, the main causes were digestive system disorders (12\%), infectious diseases (10\%), and lesions or accidents $(10 \%)$. The main causes of mortality of maned wolves in captivity (group 4) were parental incompetence (38\%), infectious diseases (9\%), and digestive system disorders (7\%).
\end{abstract}

Key words: maned wolf, studbook, management, mortality, diseases.

\section{RESUMO}

\section{Natalidade e mortalidade de lobos-guarás em cativeiro}

O objetivo deste estudo foi verificar a distribuição de nascimentos e as principais causas de mortalidade de lobos-guarás cativos, com base nos registros de nascimento e óbito no International Studbook for Maned Wolf, no período de 1980-98. Foram analisadas 361 parições, no período de 1989-98, a fim de verificar a distribuição de nascimentos e o tamanho médio das ninhadas. Os animais foram distribuídos em quatro grupos para análise das causas de mortalidade: 1. filhotes nascidos em cativeiro que morreram com menos de um ano de idade; 2 . espécimes nascidos em cativeiro que morreram com mais de um ano de idade; 3 . espécimes capturados na natureza que morreram com qualquer idade; e 4. lobos-guarás mortos no período de 1980-98. No grupo 1, as principais causas de mortalidade foram incompetência parental (67\%), doenças infecciosas (9\%) e alterações do sistema digestivo (5\%). A mortalidade média de filhotes foi de $56 \%$. A incompetência parental foi responsável por $95 \%$ das mortes dos filhotes na primeira semana de vida. No grupo 2, as principais causas foram eutanásia (18\%), alterações gênitourinárias $(10 \%)$ e alterações do sistema digestivo (8\%). As eutanásias ocorreram devido à senilidade, alterações congênitas, doenças degenerativas e traumas. No grupo 3, as principais causas foram alterações no aparelho digestivo (12\%), doenças infecciosas (10\%) e lesões e acidentes (10\%). As prin- 
cipais causas de mortalidade de lobos-guarás em cativeiro, no período de 1980-98, foram incompetência parental (38\%), doenças infecciosas (9\%) e alterações do sistema digestivo (7\%).

Palavras-chave: lobo-guará, studbook, manejo, mortalidade, doenças.

\section{INTRODUCTION}

Management plans and conservation programs have been introduced on several continents, to increase our knowledge about captive maned wolves, Chrysocyon brachyurus. These programs try to establish policies to optimize captivity management. In 1979, the International Studbook for Maned Wolves (ISMW) appeared (Roeben, 1980), and has since been published annually by Zoologisher Garten Frankfurt in census form. The ISMW gathers records and information on animals in zoos. The aims of the present study were to verify distribution of births and causes of mortality in maned wolves in captivity during the period from 1980 to 1998, using ISMW records (Matern, 1991; Roeben, 1980).

\section{MATERIAL AND METHODS}

The database was constructed from ISMW registries of deaths $(n=1,496)$ and births $(n=1,532)$ for the 1980-98 period. These registries supply the following information: studbook number, sex, filiation, birth and death dates, place of death, age at death, primary cause of death, and postmortem findings. To verify birth distribution by month and average litter size, 361 parturitions during the 198998 period were analized. The analysis of cause of death considered four groups of animals:

1. Pups born in captivity that died at less than one year of age $(n=854)$.

2. Animals born in captivity that died at more than one year of age $(n=345)$.

3. Animals captured in the wild, that subsequently died in captivity, regardless of their age $(n=297$; we analyzed 254 death records that noted the animal's date of arrival at the zoo).

4. All animals that died during the 1980-98 period $(\mathrm{n}=1,496)$.

During the 1980-98 period, 1,532 (653.555. 324 ) births of maned wolves were recorded in zoos; of these, 854 (285.248.321) died. The causes of death of 826 pups with complete records were analyzed. This sample was divided into three categories: pups that died on or before the $30^{\text {th }}$ day of life, those that survived 31 to 120 days, and those that survived 121 to 365 days.

Causes of death and postmortem findings were arranged according to the following classification: infectious diseases, parasitic diseases, neoplasms, lesions and accidents (excluding lesions due to parental attack), digestive disorders, respiratory disorders, circulatory system disorders, genitourinary system disorders, euthanasia, senility, other causes, or those not evident or not recorded and, finally, parental incompetence: devoured pups, pups neglected by parents, pups attacked by the dam or by the sire, and missing and stillborn pups. Considering that in zoos births are rarely attended, it is difficult to determine if a pup found dead in the enclosure was stillborn, attacked, or neglected by the dam. For the following categories: not evident, not recorded, stillborn, found dead, starvation, disappeared, mismothering, unsuckled, ignored, pups euthanized due to parental attack, or trauma caused by adults in pups younger than 30 days, the primary cause of death was classified as parental incompetence.

\section{RESULTS AND DISCUSSION}

\section{Birth distribution}

Of the sample for the 1980-98 period analyzed, 655 (54\%) of the pups were males, and 557 (46\%) females. Analysis of 361 parturitions during the 1989-98 period revealed that the number of pups per litter ranged from one to seven, the average size being three. The breeding season of captive maned wolves is autumn, just as in the wild. In the Southern Hemisphere, the peak number of births occurs in June (winter), with copulation occurring in April (autumn). Animals transferred to or born in the Northern Hemisphere present the highest number of births in December (winter), with copulation occuring in October (autumn), 
suggesting that photoperiodism influences sexual activity in this species (Hafez, 1988). Fig. 1 compares the monthly birth distributions for the two hemispheres. Broader distribution for the Northern Hemisphere can be attributed to its more rigorous winter, with very low temperatures.

\section{Causes of death}

Analysis of the primary cause of death in maned wolves was complicated by the absence of a standardized registry in the ISMW. Most records supply postmortem findings that do not correspond to the primary cause of death. In the case of pups born in captivity, the primary cause of death is most commonly listed as "unknown", even though parental incompetence may be evident.

\section{GROUP 1 - PUPS BORN IN CAPTIVITY THAT DIED AT LESS THAN ONE YEAR OF AGE}

Among 1,532 births recorded during the 1980-98 period, only 678 (44.3\%) survived for more than one year (Fig. 2). The rates were similar for the sexes: $56 \%$ (369/653) for males, and 55\% (307/555) for females. The average mortality rate was $53.3 \%\left(s_{x}=12.3\right)$. The dead animals were 285 males $(53.5 \%)$ and 248 females $(46.5 \%)$. The deviation in favor of males was not significant $\left(\chi_{2}\right.$, $\mathrm{p}<0.05)$. In 321 cases, the sex of the dead pup was not determined.
In Fig. 3 the number of pup deaths is analyzed by 30 -day intervals. Complete records for 28 pups that died within a year were not available for 198081 . The main causes of pup death, based on 854 records, were: parental incompetence $(66.1 \%)$; infectious diseases; digestive system disorders, including nine instances of gastroenteritis and 14 of enteritis; lesions and accidents; and respiratory disorders, including 14 cases of pneumonia. During the 1982-98 period, $77.7 \%\left(\mathrm{~s}_{\mathrm{x}}=10.5\right)$ of pup deaths occurred during the first 30 days of life, $14.9 \%$ between 31-120 days, and 7.3\% between 121-365 days (Fig. 3). In the first 30 days, the main causes of death were parental incompetence $(88.1 \%)$, infectious diseases, and respiratory disorders (Table 1). The infectious diseases included seven clinical diagnoses of canine distemper virus (CDV). During the first week of life, $94.5 \%$ of the deaths were attributed to parental incompetence. After the first week this fraction decreased, and the portion of deaths attributable to infectious diseases and pneumonia grew.

The high mortality due mainly to parental incompetence in the first days of life (Fig. 4) led several zoos to separate pups for hand-rearing (Barbiers, 1990). In Brazil, 12 pups were handreared at the breeding station in 1990. Of these, 11 died due to infections CDV and canine parvovirus (CPV) stemming from frequent contact with humans and thus indirectly with domestic animals (Velloso, 1991).

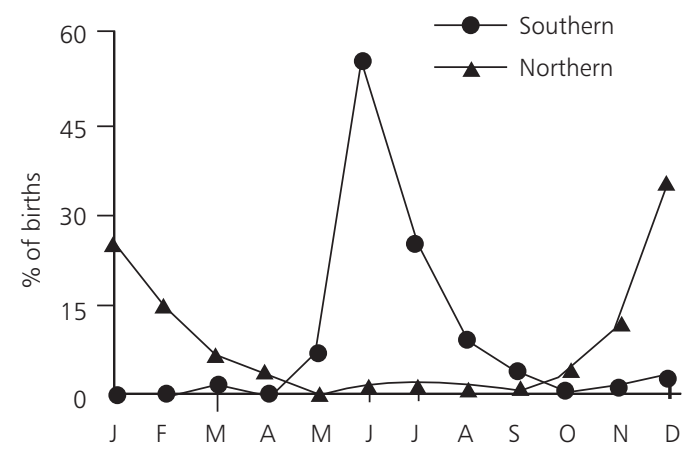

Fig. 1 - Distribution of maned wolf births in the Southern and Northern Hemispheres during the years 1989-98. 


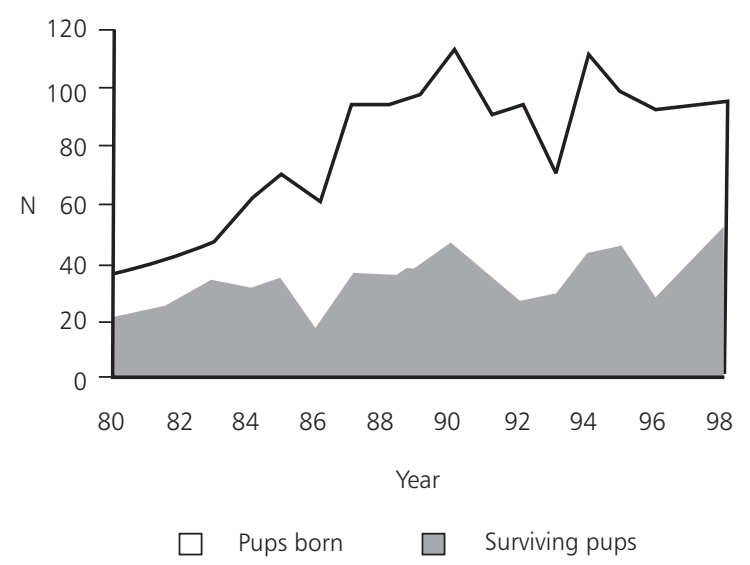

Fig. 2 - Birth and survival of manedwolf pups born in captivity during the 1980-98 period.

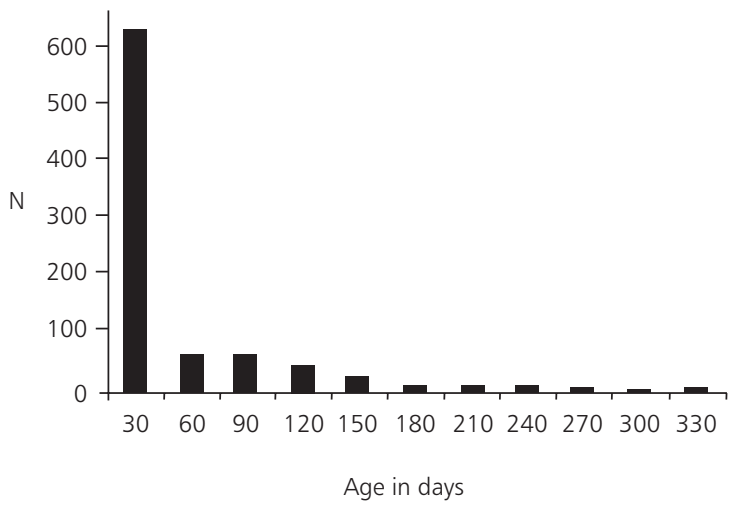

Fig. 3 - Mortality of maned wolves younger than one year by 30-day intervals for the 1982-98 period.

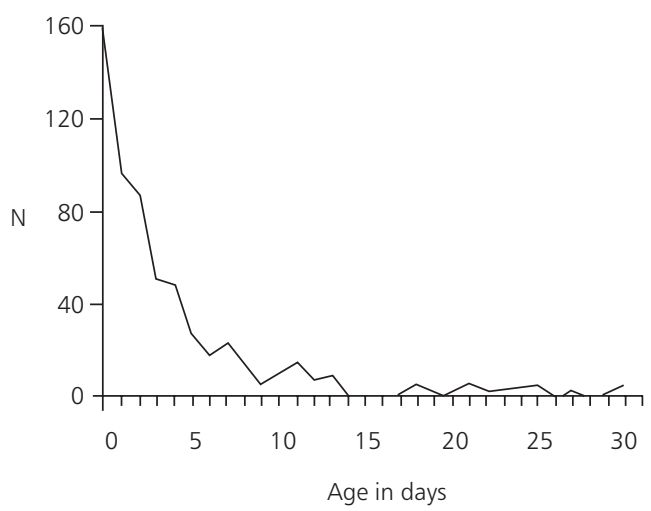

Fig. 4 - Mortality of maned wolves during the first 30 days of life during the 1982-98 period. 
At that time, vaccination of maned wolves was not a common practice in Brazilian zoos.

Proper management of maned wolves in captivity is still surrounded by mystery, in spite of the efforts of countless institutions. In an effort to understand the high pup mortality due to parental incompetence, some zoos have been equipped with sophisticated monitoring systems. Several authors have suggested that disturbances in the immediate environment (excessive noise; presence of visitors, keepers, and technicians; inadequate, poorly furnished enclosures; lack of privacy), can frustrate the dam's attempts to move the pups to a safer place, leading her to neglect or kill her pups (Faust \& Scherpner, 1967). In several zoos, females have been observed changing their pups' nest (Velloso, 1991). Hand-rearing, however, requires a substantial infrastructure for isolation, sanitary conditions, care, and feeding of pups. It is only recommended in the case of couples or dams that present behaviors considered dangerous to the pups, and principally for those couples designated as "priority" animals based on their genetic value to the population (Fletchall et al., 1995). The male in some instances participates actively in rearing the pups (Bartmann \& Nordhaff, 1984), but in other cases remains distant, hardly interacting with the dam or litter (Veado, 1997). Records also exist of pups being killed by the sire (Matern, 1981-1998).

In pups aged 31 to 120 days old, the main causes of death were infectious diseases, digestive disorders, parental incompetence, and lesions and accidents (Table 1). Among the infectious diseases, we noted 18 cases attributed to CPV and 12 to CDV, responsible for $22 \%$ of the deaths in that group. Digestive disorders, reported included seven cases of hemorrhagic gastroenteritis and 13 of enteritis; the latter disorders are frequently observed in animals infected with CPV and CDV. Available records do not indicate whether the infected pups were hand-reared or reared by the parents, nor do they provide a vaccination history of the pups or parents. These records corroborate evidence of several authors that shows susceptibility of maned wolves to viruses common to domestic dogs (Cabasso et al., 1956; Mann et al., 1980). Considering the susceptibility to infectious diseases, and low probability of abandonment by parents starting from 30 days of age, vaccination of the pups beginning at 45-60 days of age is justifiable.
The main causes of death of pups 121 to 365 days old (Table 1) were infectious diseases, digestive disorders, euthanasia, and lesions and accidents. Amongst the infectious diseases were seven cases of CPV, three of CDV, and two of adenovirus, responsible for $19.7 \%$ of the deaths in that group. Among the digestive disorders, cases of hemorrhagic gastroenteritis and enteritis were found $(11.5 \%)$.

\section{GROUP 2 - ANIMALS BORN IN CAPTIVITY THAT DIED AFTER ONE YEAR OF AGE}

The cause-of-death analysis for this group (pups born in captivity that reached adulthood) was based on the death records for the 1982-98 period. According to the ISMW, 345 pups born in captivity died after the first year of life. The average age at death in this group was 7.3 years; $32.5 \%(112 / 345)$ of the animals died at more than ten years of age. Records show animals reaching 16 years of age. The main causes of death are listed in Table 1. The high percentage of euthanasias was due to the high number of senile animals. At least $50 \%$ of the euthanasias can be related to multiple and concurrent degenerative disorders characterized by neoplasms and renal, heart, and liver lesions.

At least $45 \%$ of the urinary system disorders were attributed to senility. The most frequent problem was the formation of calculi, with five records of cystinuria, a metabolic disease characterized by excessive excretion of cystine and other amino acids in the urine, with formation of calculi and obstruction of ducts, which can lead to rupture of the bladder (Boveé et al., 1981), and death. Cystinuria seems to be associated with a diet rich in animal protein.

\section{GROUP 3 - ANIMALS CAPTURED IN THE WILD}

Table 1 lists the main causes of death of maned wolves captured in the wild: disorders of the digestive system, infectious diseases, respiratory disorders, and lesions and accidents. This group showed the largest percentage of cases without records of postmortem findings. Among the infectious diseases, there were records of CDV, encephalitis, septicemia, tuberculosis, leptospirosis, and hepatitis, again demonstrating the susceptibility of the maned wolf to diseases that attack domestic dogs. 
TABLE 1

Causes of mortality of maned wolves in captivity during the period 1980-98, divided into four groups.

\begin{tabular}{|c|c|c|c|c|c|c|c|c|c|c|c|c|c|c|}
\hline \multirow{4}{*}{ Causes of deaths } & \multicolumn{14}{|c|}{ Groups } \\
\hline & \multicolumn{8}{|c|}{ Group $1^{1}$} & \multicolumn{2}{|c|}{ Group 2} & \multicolumn{2}{|c|}{ Group 3} & \multicolumn{2}{|c|}{ Group 4} \\
\hline & \multicolumn{2}{|c|}{ 0-30 days } & \multicolumn{2}{|c|}{$\begin{array}{c}\text { 31-120 } \\
\text { days }\end{array}$} & \multicolumn{2}{|c|}{$\begin{array}{c}\text { 121-365 } \\
\text { days }\end{array}$} & \multicolumn{2}{|c|}{$\Sigma$} & \multirow[b]{2}{*}{$\mathrm{n}$} & \multirow[b]{2}{*}{$\%$} & \multirow[b]{2}{*}{$n$} & \multirow[b]{2}{*}{$\%$} & \multirow[b]{2}{*}{11} & \multirow[b]{2}{*}{$\%$} \\
\hline & $\mathrm{n}$ & $\%$ & $\mathrm{n}$ & $\%$ & $\mathrm{n}$ & $\%$ & $\mathrm{n}$ & $\%$ & & & & & & \\
\hline Parental incompetence & 550 & 84.7 & 18 & 13.2 & 1 & 1.4 & 569 & 66.6 & 0 & 0 & 0 & 0 & 569 & 38.0 \\
\hline Infectious diseases & 21 & 3.2 & 45 & 33.1 & 12 & 17.4 & 78 & 9.1 & 22 & 6.4 & 31 & 10.4 & 131 & 8.8 \\
\hline Parasitic diseases & 0 & 0.0 & 1 & 0.7 & 1 & 1.4 & 2 & 0.2 & 13 & 3.8 & 18 & 6.1 & 33 & 2.2 \\
\hline Lesions and accidents & 8 & 1.2 & 19 & 14.0 & 5 & 7.2 & 32 & 3.7 & 20 & 5.8 & 31 & 10.4 & 83 & 5.5 \\
\hline $\begin{array}{l}\text { Digestory system } \\
\text { disorders }\end{array}$ & 10 & 1.5 & 24 & 17.6 & 12 & 17.4 & 46 & 5.4 & 28 & 8.1 & 35 & 11.8 & 109 & 7.3 \\
\hline Respiratory disorders & 20 & 3.1 & 2 & 1.5 & 1 & 1.4 & 23 & 2.7 & 17 & 4.9 & 27 & 9.1 & 67 & 4.5 \\
\hline $\begin{array}{l}\text { Genitourinary system } \\
\text { disorders }\end{array}$ & 0 & 0.0 & 0 & 0.0 & 1 & 1.4 & 1 & 0.1 & 35 & 10.1 & 15 & 5.1 & 51 & 3.4 \\
\hline $\begin{array}{l}\text { Circulatory system } \\
\text { disorders }\end{array}$ & 0 & 0 & 1 & 0.7 & 2 & 3 & 3 & 0 & 16 & 4.6 & 8 & 2.7 & 27 & 1.8 \\
\hline Neoplasmas & 0 & 0.0 & 0.0 & 0.0 & 0 & 0.0 & 0 & 0.0 & 19 & 5.5 & 3 & 1.0 & 22 & 1.5 \\
\hline Euthanasia & 6 & 0.9 & 4 & 2.9 & 7 & 10.1 & 17 & 2.0 & 61 & 17.7 & 20 & 6.7 & 98 & 6.6 \\
\hline $\begin{array}{l}\text { Other causes or not } \\
\text { evident }\end{array}$ & 6 & 0.9 & 14 & 10.3 & 17 & 24.6 & 37 & 4.3 & 59 & 17.1 & 37 & 12.5 & 133 & 8.9 \\
\hline No report & $28^{1}$ & 4.3 & 8 & 5.9 & 10 & 14.5 & $46^{1}$ & 5.4 & 55 & 15.9 & 72 & 24.2 & 173 & 11.6 \\
\hline TOTAL & $649^{1}$ & 100.0 & 136 & 100.0 & 69 & 100.0 & $854^{1}$ & 100.0 & 345 & 100.0 & 297 & 100.0 & 1496 & 100.0 \\
\hline
\end{tabular}

${ }^{1}$ Including 28 pups with incomplete records.

Among the parasitic diseases, we point out six deaths from anemia due to heavy infestation with fleas, evidencing the high susceptibility of maned wolves to these ectoparasites. However, commercial products for domestic dogs have been shown to be effective in the control of fleas and ticks. Infection with Dioctophyme renale was observed in seven maned wolves captured in the wild (Dietz, 1984). The impact of these afflictions on wild populations of maned wolves has not been studied in detail, and should be the subject of field investigations. According to ISMW, during the 1980-98 period 305 maned wolves were captured in the wild and sent to zoos (Fig. 5). Nevertheless, some of the animals that died shortly after capture were not recorded. The analysis, based on 254 complete records of animals captured during the 1980-98 period, revealed that only 46 (20.4\%) animals died during the first month following capture, showing the adaptability of this species to life in captivity. In some zoos, recently captured animals are fed meat exclusively because they reject dog food and fruits. However, such adaptability is not verified in relation to reproductive behavior, i.e., formation of the reproductive pair and care of the pups. For captured animals, the mean survival time in captivity was 3.4 years. Probably the increase in the number of animals captured over the years was due to increasing occupation of savannah for agricultural purposes, forcing the animals to look for food on farms or near cities, and rendering them more likely to be hunted, captured, killed on roads, and more susceptible to illnesses that attack domestic dogs. In Brazil, there has been a larger concentration of captures in São Paulo $(n=91)$, Goiás $(n=67)$ and Minas Gerais $(n=62)$, all states with predominantly savannah (cerrado) vegetation. 


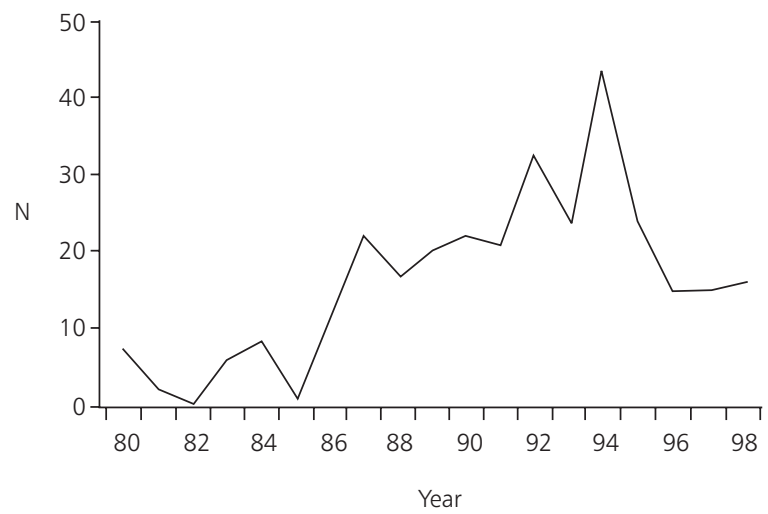

Fig. 5 - Number of maned wolves captured in the wild during the 1980-98 period.

\section{GROUP 4 - ANIMALS THAT DIED DURING THE 1980-98 PERIOD}

The main causes of death of captive maned wolves during the 1980-98 period are listed in Table 1. Parental incompetence represents the main cause of mortality in captivity, due to the great number of pups that are eaten by the parents during the first days of life. CPV, CDV and hepatitis were responsible for $53 \%$ of the deaths due to infectious disease. The two more frequent viruses were CPV $(21.5 \%)$ and CDV (19.4\%). Overall, these two viruses were responsible for the death of $3.8 \%$ (57/1496) of captive animals. Pups younger than one year of age, and animals captured in the wild showed a higher rate of infection. Immunoprophylaxis against CPV and CPV can be performed with a modified-live vaccine developed for domestic dogs (Maia \& Gouveia, 2001). Parasitic diseases were more frequent in animals captured in the wild. Most of the death records were for animals from American $(21 \%)$, German (17.5\%), and Brazilian (10.8\%) zoos, countries that represent the largest ex situ populations of maned wolves, and that have management plans for the species. Several deaths could have been avoided if a greater exchange of information had existed about these management plans, and their recommendations disseminated and adopted by zoos.

\section{CONCLUSIONS}

Although the analysis presented in this study was hampered by the lack of standardized records of primary cause of death, it suggests certain preventive measures that can optimize the management of maned wolves in captivity. It is essential that all zoos send complete reports to the Studbook and perform and record autopsies of all animals. In a significant fraction of the cases (13.6\%), postmortem findings were lacking; also common were "not evident", "no report", and "no information" entries. Efforts should be made to develop a standard questionnaire so as to facilitate a more precise analysis of the records. Breeding maned wolves in captivity is a great challenge. Several studies on reproductive behavior are being conducted in order to optimize pup handling and survival. Reproduction programs should be careful in mate selection. They should try to maintain the genetic variability of captive populations and avoid overpopulation. Field studies should be done to supply information for captive management and reintroduction programs. It is necessary to develop educational campaigns aimed at preserving the natural habitat of this species so that it, as well as so many others, will not be found only in captivity, and the zoos will not become museums of live fauna.

\section{REFERENCES}

BARBIERS, R., 1990, Natural history and captive management of maned wolves. Proc. Am. Ass. Zoo. Vet., pp. 5860 .

BARTMANN, W. \& NORDHOFF, I., 1984, Paarbindung und elternfamilie beim mahnenwölfe (Chrysocyon brachyurus). Zeitschrift des Kölner Zoo, 27: 63-71.

BOVÉE, K. C., BUSH, M., DIETZ, J., JEZKY, P. \& SEGAL, S., 1981, Cystinuria in the maned wolf of south america. Science, 212: 919-920. 
BURTON, M. \& RAMSAY, E., 1986, Cryptorchidism in maned wolves. J. Zoo An. Med., 17: 133-135.

CABASSO, V. J., SCHROEDER, C. R. \& STEBBINS, M. R., 1956, Isolation of distemper virus from the south american maned wolf (Chrysocyon jubatus). Veterinary Medicine, 7: 330-332.

DIETZ, J. M., 1984, Ecology and social organization of maned wolf (Chrysocyon brachyurus). Washington, Smithosonian Contribuition to Zoology, 51p.

FAUST, R. \& SCHERPNER, C., 1967, A note on the breeding of maned wolf (Chrysocyon brachyurus) at $\mathrm{t}$ the Frankfurt Zoo. Intern. Zoo. Year, 7: 119.

FLETCHALL, N. B., RODDEN, M. \& TAYLOR, S., 1995, Husbandry manual for the maned wolf Chrysocyon brachyurus. AAZV, Washington, 93p.

FYVIE, A., 1971, Dioctophyma renale. In: J. W. Davis \& R. C. Anderson (eds.), Parasitc diseases of wild animals. Ames: The Iowa State University Press, pp. 258-262.

GINSBERG, J. R. \& MACDONALD, D. W., 1990, Foxes, wolves, jackals ans dogs: an actionplan for the conservation of canids. Gland: IUCN/SSC Canid Specialis Group \& IUCN/SSC Wolf Specialist Group, International Union for Conservation of Nature and Natural Resources (IUCN), 116p.

HAFEZ, E. S. E., 1988, Reprodução Animal. 4.ed. Editora Manole Ltda., São Paulo, 720p.

MAIA, O. B. \& GOUVEIA, A. M. G., 2001, Serologic response of maned wolves (Chrysocyon brachyurus) to canine distemper virus and canine parvovirus vaccination. J. Zoo. Wild. Med., 32(1): 78-80.
MANN, P. C., BUSH, M., APPEL, M. et al., 1980, Canine parvovirus infection in south american canids. J. Am. Vet. Med. Assoc., 177: 779-783.

MATERN, B., 1981-1998, Internationales register und zuchtbuch für den mähnenwolf Chrysocyon brachyurus (Illiger, 1811). Frankfurt am Main: Zoologisher Garten Frankfurt.

MATERN, B., 1991, Guideline for keeping the maned wolf Chrysocyon brachyurus (Illiger, 1811). Frankfurt am Main: Zoologisher Garten Frankfurt, 14p.

ROEBEN, P., 1975, Studbooks for the maned wolf, bush dog and spectacled bear, Chrysocyon brachyurus, Speothus venaticus and Tremarctos ornatus. Intern. Zoo. Year, 15 287-300.

ROEBEN, P., 1980, Internationales register und zuchtbuch für den mähnenwolf Chrysocyon brachyurus (Illiger, 1811). Frankfurt am Main: Zoologisher Garten Frankfurt.

VEADO, B. V., 1997, Parental behaviour in maned wolf Chrysocyon brachyurus at Belo Horizonte Zoo. Intern. Zoo. Year., 35: 279-286.

VELLOSO, A. L., 1991, Captive breeding and behaviour of maned wolf (Chrysocyon brachyurus) in brazilian zoos. Monografia, Jersey Wildlife Preservation Trust Jersey. 